\title{
Disappearance of amino acids from the gastro-intestinal tract of dairy cows fed soyabean meal or fish meal diets*
}

\section{Angela Schröder' ${ }^{1}$ K.-H. Südekum', M. Brandt ${ }^{3}$ and M. Gabel ${ }^{2}$}

\author{
'Institute of Animal Nutrition, Physiology and Metabolism, \\ Christian-Albrechts-University \\ D-24098 Kiel, Germany \\ ${ }^{2}$ Institute for Ecologically Compatible Animal Husbandry, University of Rostock \\ D.18051 Rostock, Germany \\ ${ }^{3}$ Current address: Moorburger Elhdeich 263 \\ D-21079 Hamhurg, Germany
}

(Received 15 July 1996; accepted 6 February 1997)

\begin{abstract}
Four German Fricsian cows, fitted with cannulas in the rumen, duodenum and ileum, were fed on diets containing similar amounts of rumen-degradable organic matter and crude protein, and soyabean meal or fish meal as the major protein source. The disappearance of organic matter, nitrogen and amino acids (AA) from the stomachs and from the small and large intestines was determined. Digestibilities of organic matter, nitrogen and AA in the stomachs were similar for both diets. A trend was observed for greater disappearance of these components from the small intestine of cows fed the fish meal diet. The comparison of the AA composition of duodenal digesta with that of the diets indicated that ruminal fermentation altered the AA profile of fish meal less than that of soyabean meal. Disappearance of individual AA from the small intestine differed within and between diets. Preferential disappearance of essential AA from the small intestine compared with non-essential AA was observed. We conclude that the protein value of feedstuffs in terms of absorbed AA should be evaluated separately for fecdstuff and individual AA.
\end{abstract}

KEY WORDS: dairy cow, amino acids, disappearance, gastro-intestinal tract, fish meal, soyabean meal

* In honour of Prof. Dr. Dr. K. Drepper 


\section{INTRODUCTION}

Amino acids (AA) are supplied to the duodenum of dairy cows by microbial protein synthesized in the rumen, rumen-undegraded dietary protein and endogenous protein. On average, microbial nitrogen $(\mathrm{N})$ supplies $59 \%$ of the non-ammonia-N (NAN) in duodenal digesta of dairy cows (Clark et al., 1992). Therefore, the AA composition of protein in duodenal digesta should reflect that of microbial protein. From a survey of literature data, Merchen and Titgemeyer (1992) concluded that proportions of individual essential AA (EAA) in duodenal digesta are not greatly divergent from those in ruminal bacteria, except for leucine and lysine. When the extent of ruminal protein degradation, however, is very low or AA release from feeds differs among individual AA or both, AA composition of duodenal digesta may be altered largely due to a greater proportion of rumen-undegraded feed protein. According to Erasmus (1991), manipulations of duodenal AA profile have only been successful when supplemental protein supplied about half of the total dietary protein.

Fish meal (FM) contains high-quality protein (Agricultural Research Council, 1980) with an AA composition close to that required for growth and milk production (Atwal and Erfle, 1992). From studies conducted in vitro (Hussein et al., 1991) and in situ (Susmel et al., 1989; Petit, 1992; Martillotti et al.,1995), it is obvious that FM protein is more resistant to ruminal degradation than protein from soyabean meal (SBM). Based on the amounts of intestinally absorbed AA, FM has been judged a valuable source of rumen-undegraded protein for rapidly growing steers (Keery et al,, 1993). To the authors' knowledge, no studies report on the fate of ruminally undegraded AA from FM within the small and large intestines of dairy cows. Recent developments in protein evaluation systems for ruminants have focused on supply of individual AA to and disappearance from the small intestine to determine individual $\mathrm{AA}$ rather than protein requirements of cattle (Iburg, 1993; van Straalen, 1995; Schwab, 1996). The objectives of this study were to compare the AA composition of duodenal digesta and the disappearance of individual AA from the small intestine of dairy cows fed rations containing similar amounts of rumen-degradable organic matter (OM) and $\mathrm{CP}$, but differing in the major CP source, i.e. SBM or FM.

\section{MATERIAL AND METHODS}

\section{Animals and diets}

Four German Friesian cows (two lactating, two non-lactating) fitted with permanent ruminal, duodenal and ileal cannulas (Brandt et al., 1984), were used. 
TABLE 1

Composition of soyabean meal and fish meal diets, $\%$ of dry matter

\begin{tabular}{lcc}
\hline & \multicolumn{2}{c}{ Dict } \\
\cline { 2 - 3 } Ingredient & soyabean meal & fish meal \\
\hline Grass hay & 39.1 & 42.6 \\
Soyabean meal & 25.6 & - \\
Fish meal & - & 20.9 \\
Tapioca & 29.5 & 31.0 \\
Mineral-vitamin mixture & 5.8 & 5.5 \\
\hline
\end{tabular}

TABLE 2

Chemical composition of dietary ingredients, $\mathrm{g} / \mathrm{kg}$ of dry matter

\begin{tabular}{|c|c|c|c|c|}
\hline \multirow{2}{*}{ Item } & \multicolumn{4}{|c|}{ Ingredient } \\
\hline & soyabean meal & fish meal & grass hay & tapioca' $^{\prime}$ \\
\hline Crude protein & 530 & 730 & 120 & 24 \\
\hline Acid ether extract ${ }^{2}$ & 19 & 52 & 35 & 8 \\
\hline Ash & 65 & 192 & 64 & 61 \\
\hline Crude fibre & 50 & 16 & 310 & 46 \\
\hline Nitrogen-free extractives & 337 & 12 & 467 & 861 \\
\hline $\mathrm{TAA}^{3}$ & 553 & 765 & 103 & \\
\hline $\mathrm{EAA}^{4}, \mathrm{~g} / 100 \mathrm{~g} \mathrm{AA}$ & 44.5 & 48.6 & 47.0 & \\
\hline leucine & 7.8 & 8.3 & 9.8 & \\
\hline lysine & 6.6 & 8.6 & 5.5 & \\
\hline valine & 4.9 & 5.6 & 6.8 & \\
\hline arginine & 7.8 & 6.6 & 5.4 & \\
\hline threonine & 4.1 & 4.8 & 5.2 & \\
\hline isoleucine & 4.4 & 4.7 & 4.5 & \\
\hline phenylalanine & 5.0 & 3.9 & 5.5 & \\
\hline histidine & 2.5 & 3.0 & 1.9 & \\
\hline methionine & 1.3 & 3.0 & 2.4 & \\
\hline $\mathrm{NE}: A \mathrm{~A}^{b}, \mathrm{~g} / 100 \mathrm{~g} \mathrm{AA}$ & 55.5 & 51.4 & 53.0 & \\
\hline glutamic acid & 18.2 & 14.0 & 12.0 & \\
\hline aspartic acid & 11.4 & 10.5 & 10.7 & \\
\hline glycine & 4.4 & 7.1 & 5.7 & \\
\hline alanine & 4.3 & 6.1 & 7.3 & \\
\hline tyrosine & 3.5 & 3.1 & 3.8 & \\
\hline serine & 4.9 & 5.2 & 4.9 & \\
\hline proline & 7.5 & 4.2 & 5,6 & \\
\hline cystine & 1.4 & 1.3 & 3.0 & \\
\hline
\end{tabular}

${ }^{1}$ not analysed for amino acids because of low crude protein content

${ }^{2}$ acid hydrolysis prior to extraction

${ }^{3}$ total amino acids

${ }^{4}$ essential amino acids

${ }^{5}$ non-essential amino acids 
Two diets were formulated to provide identical amounts of rumen-degradable $\mathrm{OM}$ and $\mathrm{CP}$ in the dry matter (DM) of the diet, but from two different protein sources, SBM or FM. Based on an in situ study of Susmel et al. (1989), who estimated CP degradability in cows receiving forage and concentrate in proportions (48:52) similar to those used in this study, rumen-degradable CP was assumed to be 54 and $41 \%$ of CP for SBM and FM, respectively. Because the CP content of the SBM was higher than calculated, the SBM contributed about one percentage unit more rumen-degradable CP than FM to the respective diet DM. For the whole diet, this difference was even smaller, because the FM diet contained more rumen-degradable CP from hay as a result of the greater hay proportion in the DM of this diet (Table 1). Due to the principal aim of diet formulation, the ingredient (Table 1) and chemical composition (Table 2) of the diets differed slightly. Soyabean meal or FM contributed 70 and $72 \%$ to total dietary CP, respectively. The diets containing the respective protein sources are hereafter referred to as the SBM diet and the FM diet. All feedstuffs were obtained commercially. The grass hay was a second cut from a lowland bog and was fed in the long, unchopped form. Tapioca was offered as a meal. According to the manufacturer's information, the SBM was toasted at $102^{\circ} \mathrm{C}$ for $20 \mathrm{~min}$. To ensure complete intake, 1.7 and $2.7 \%$ (DM basis) propionic acid $(10 \%, \mathrm{v} / \mathrm{v})$ were added to the FM diet in periods 1 and 2, respectively. The daily allotment of feed was offered in two equal meals at 07:00 and 19:00 h. Water was freely available at all times.

\section{Experimental design}

The two diets were fed to the cows in a two-period changeover design, i.e. all variables that are reported hereafter are the mean of four observations for each diet unless otherwise indicated. Experimental periods were 27 days long. Days 1 to 18 were for dietary adaptation. Sample collections were on days 19 to 27 .

\section{Sample collection}

Representative samples of the feedstuffs were obtained from each dictary ingredient, pooled by period and stored at room temperature for subsequent analyses. Feed refusals were collected twice daily, dried at $40^{\circ} \mathrm{C}$, pooled by animal over the collection period and stored like dietary ingredients until analyzed. Ruminal fluid was collected on day 20 of period 1 and on day 19 of period 2 and on day 27 of both periods. Samples were taken immediately before the morning feeding $(0 \mathrm{~h})$ and at $1,2,3,5$ and $8 \mathrm{~h}$ after the morning feeding. Collection and storage of ruminal fluid prior to analyses were as described previously (Schröder et. al., 1989). The $\mathrm{pH}$ of ruminal fluid was measured 
immediately after the sample was taken. Duodenal and ileal digesta were spot sampled at 3- and 6-h intervals, respectively, from day 21 to 26 (Schröder et al., 1989). Total faecal collections and storage of digesta and faeces also were as reported by Schröder et al. (1989).

\section{Marker administration}

In order to estimate the flow of digesta through the gastro-intestinal tract, chromium ethylene diamine-tetra-acetic acid (Cr EDTA) was used as a marker. A solution of $\mathrm{Cr}$-EDTA in water $(1.108 \mathrm{~g} \mathrm{Cr} / \mathrm{I})$ was infused continuously into the ventral sac of the rumen at a rate of approximately $1.3 \mathrm{l} /$ day.

\section{Analytical procedures}

The DM of feedstuffs and feed refusals was determined by oven-drying at $105^{\circ} \mathrm{C}$ overnight. The DM of digesta and faeces was estimated by freeze-drying and subsequent oven drying at $105^{\circ} \mathrm{C}$. Thawed fresh matter was used for determination of $\mathrm{N}$ and ammonia- $\mathrm{N}\left(\mathrm{NH}_{3}-\mathrm{N}\right)$ in ileal digesta and faeces. Freeze-dried digesta and faeces were used for all other analyses. Ruminal fluid, duodenal and ileal digesta and faeces were analyzed for $\mathrm{NH}_{3}-\mathrm{N}$ by steam distillation according to Brandt (1979). Nitrogen in feedstuffs, digesta materials and faeces was analyzed by the Kjeldahl procedure (Naumann et al.,1976). Cr-EDTA in infusion solutions, digesta and faeces was analyzed photometrically as described by Brandt and Kühn (1987). Samples of feedstuffs, digesta and faeces for AA analyses were hydrolyzed in $6 \mathrm{M} \mathrm{HCl}$ at $132^{\circ} \mathrm{C}$ in an autoclave for $3 \mathrm{~h}$. For sulphur AA, samples were oxidized with hydrogen peroxide: formic acid $(1: 9, \mathrm{v} / \mathrm{v})$ at $4^{\circ} \mathrm{C}$ for $24 \mathrm{~h}$, followed by $6 \mathrm{M} \mathrm{HCl}$ at $132^{\circ} \mathrm{C}$ in an autoclave for $3 \mathrm{~h}$. Amino acids were analyzed by ion-exchange chromatography in an AA analyzer (Model T 339 M; Microtechna, Prague).

\section{Calculations and statistical analysis}

Amounts of digesta constituents entering the duodenum and ileum in $24 \mathrm{~h}$ were estimated from their ratio to the non-absorbed marker Cr-EDTA (a correction was made assuming an absorption in the rumen, small intestine and large intestine of $2,0.5$ and $0.5 \%$, respectively; $\mathrm{M}$. Brandt, unpublished observations, 1979) in the appropriate digesta samples (corrected for incomplete recovery in the faeces) and the $24 \mathrm{~h}$ intakes of the markers.

For the comparison of the AA composition of the protein in the diets and in duodenal digesta, the method of Guilloteau et al. (1986) was used. In this method the similarity between two AA profiles is expressed in the distance in chi': 


$$
X^{2}=\sum_{k-1}^{17}\left(\mathrm{AA}_{\mathrm{ik}}-\mathrm{AA}_{\mathrm{jk}}\right)^{2} /\left(\left(\mathrm{AA}_{\mathrm{ik}}+\mathrm{AA}_{\mathrm{jk}}\right) / 2\right)
$$

In this equation $\mathrm{AA}_{\mathrm{ik}}$ and $\Lambda \Lambda_{\mathrm{jk}}$ are the respective percentages of $\mathrm{AA} \mathrm{k}$ in total AA (TAA) of diet $i$ and of duodenal digesta $j$.

Data were subjected to analysis of variance considering diet, animal and period as fixed effects. Diet effects were declared significant at $\mathrm{P}<0.10$ unless otherwise indicated.

\section{RESULTS}

The daily intakes of DM and CP and the proportions of AA in TAA of the diets are given in Table 3 . The DM intakes were similar for the two diets but cows receiving the $\mathrm{SBM}$ diet consumed less $\mathrm{CP}$, resulting in different $\mathrm{CP}$ concentrations in total diet DM. The AA profiles of the diets reflected the differences observed for SBM and FM (Table 2).

Ruminal variables are shown in Table 4 . Average ruminal $\mathrm{NH}_{3}-\mathrm{N}$ concentrations were different between diets. At all time points, values were greater for the SBM diet than the FM diet and all differences were significant with the exception of the 0 and $5 \mathrm{~h}$ values. No clear postprandial peak of $\mathrm{NH}_{3}-\mathrm{N}$ concentrations was observed for either diet. Ruminal $\mathrm{pH}$ values were higher for the FM diet than for the SBM diet and the differences were significant at 2 and $8 \mathrm{~h}$ postfeeding.

Daily intakes of $\mathrm{OM}$ and digestibility of $\mathrm{OM}$ in the stomachs, the small intestine and the large intestine were similar for both diets (Table 5), although numerical values indicate that the OM of the FM diet was more digestible in the small intestine than the OM of the SBM diet. Total tract digestibilities of OM were high for both diets and slightly but significantly greater for the SBM than for the FM diet.

Variables of $\mathrm{N}$ intake and digestion are presented in Table 6 . As indicated by the NAN flow to the duodenum compared with $\mathrm{N}$ intake and by apparent digestibility of $\mathrm{N}$ in the stomachs, the NAN flow to the duodenum was almost identical to $\mathrm{N}$ intake for both diets. When daily NAN flow to the duodenum was related to OM apparently digested in the stomachs or in the total tract, higher values were observed for the FM diet. However, none of the differences were significant. The apparent digestibilities of $\mathrm{N}$ in the stomachs and total tract and the apparent digestibilities of NAN in the small intestine and large intestine were not different $(\mathrm{P}>0.10)$ between the two diets, although numerical values indicate that the FM diet had slightly higher digestibilities in the small intestine and in the total tract. 
TABLE 3

Daily intakes of dry matter, crude protein and amino acids and crude protein content and amino acid composition of soyabcan mcal and fish mcal dicts fed to dairy cows

\begin{tabular}{lcc}
\hline & & Diet \\
\cline { 2 - 3 } Ingredient & soyabean meal & tish meal \\
\hline Dry matter, $\mathrm{kg} /$ day & 12.6 & 13.2 \\
Crude protein, g/day & 2397 & 2825 \\
Crude protein, g/kg dry matter & 190 & 214 \\
TAA', g/day & 2293 & 2681 \\
EAA $^{2}, \mathrm{~g} /$ day & 1033 & 1294 \\
NEAA ${ }^{3}$, g/day & 1261 & 1388 \\
EAA, g/100 g TAA intake & 45.0 & 48.2 \\
leucine & 8.3 & 8.6 \\
lysine & 6.4 & 8.0 \\
valine & 5.3 & 5.9 \\
arginine & 7.3 & 6.4 \\
threonine & 4.3 & 4.9 \\
isoleucinc & 4.4 & 4.6 \\
phenylalanine & 5.1 & 4.2 \\
histidine & 2.3 & 2.8 \\
methionine & 1.6 & 2.9 \\
NEAA, g/100 g TAA intake & & 51.8 \\
glutamic acid & 55.0 & 13.5 \\
aspartic acid & 16.8 & 10.5 \\
glycine & 11.3 & 6.8 \\
alanine & 4.6 & 3.4 \\
tyrosine & 5.0 & 5.1 \\
serine & 3.6 & 1.7 \\
proline & 4.9 & \\
cystine & 7.0 & \\
\hline
\end{tabular}

${ }^{1}$ total amino acids

${ }^{2}$ essential amino acids

${ }^{3}$ non-essential amino acids 
TABLE 4 Ammonia-nitrogen $\left(\mathrm{NH}_{3}-\mathrm{N}\right)$ concentrations and $\mathrm{pH}$ values in the ventral sac of the rumen of dairy cows fed a soyabean meal or fish meal diet

\begin{tabular}{|c|c|c|c|c|c|}
\hline \multirow{2}{*}{ Item } & \multirow{2}{*}{$\begin{array}{l}\text { Postfeeding } \\
\mathbf{h}\end{array}$} & \multicolumn{2}{|c|}{ Diet } & \multirow{2}{*}{ SEM } & \multirow{2}{*}{$\mathbf{P}$} \\
\hline & & soyabcan meal & fish meal & & \\
\hline \multirow[t]{6}{*}{$\mathrm{NH}_{3}-\mathrm{N}, \mathrm{mmol} / \mathrm{l}$} & 0 & 14.0 & 7.7 & 1.7 & 0.129 \\
\hline & 1 & 15.4 & 7.5 & 1.1 & 0.036 \\
\hline & 2 & 13.7 & 6.5 & 1.0 & 0.036 \\
\hline & 3 & 10.9 & 4.8 & 0.7 & 0.028 \\
\hline & 5 & 11.0 & 3.5 & 2.0 & 0.119 \\
\hline & 8 & 7.6 & 2.3 & 1.1 & 0.081 \\
\hline \multirow[t]{6}{*}{$\mathrm{pH}$} & 0 & 6.4 & 6.6 & 0.3 & 0.732 \\
\hline & 1 & 6.2 & 6.5 & 0.2 & 0.512 \\
\hline & 2 & 5.9 & 6.4 & 0.1 & 0.091 \\
\hline & 3 & 5.9 & 6.1 & 0.1 & 0.257 \\
\hline & 5 & 6.0 & 6.0 & 0.1 & 0.143 \\
\hline & 8 & 6.0 & 6.4 & 0.1 & 0.030 \\
\hline
\end{tabular}

' each value represents the average of eight observations (two observations per cow)

TABLE 5

Daily intake, duodenal flow and apparent digestibility of organic mattcr in the gastrointestinal tract of dairy cows fed a soyabcan mcal or fish meal diet

\begin{tabular}{lcccc}
\hline \multirow{2}{*}{ Item } & \multicolumn{2}{c}{ Diet } & SEM & P \\
\cline { 2 - 3 } & soyabean meal & fish meal & & \\
\hline Intake, kg/day & 11.7 & 11.8 & & \\
Flow to duodenum, kg/day & 6.0 & 6.5 & 1.1 & 0.800 \\
Apparent digestibility, \% & & & & \\
stomachs & 48.7 & 47.4 & 2.8 & 0.780 \\
small intestinc & 44.3 & 51.7 & 2.2 & 0.138 \\
large intestine & 20.3 & 4.2 & 9.6 & 0.359 \\
total tract & 77.5 & 76.6 & 0.2 & 0.063 \\
\hline
\end{tabular}


TABLE 6 Daily intakes, duodenal flow and apparent digestibilities of nitrogen (N) and non-ammonia-nitrogen (NAN) in the gastro-intestinal tract of dairy cows fed a soyabean meal or fish meal dict

\begin{tabular}{lcccc}
\hline \multirow{2}{*}{ Item } & \multicolumn{2}{c}{ Diet } & SEM \\
\cline { 2 - 3 } & soyabean meal & fish meal & & \\
\hline Intake, g/day & 384 & 452 & & \\
Flow to duodenum, & & & 60 & 0.534 \\
$\quad$ NAN, g/day & 380 & 442 & 2 & 0.164 \\
NAN, g/kg DOMT ${ }^{1}$ & 40 & 47 & 12 & 0.398 \\
NAN, g/kg DOMST ${ }^{2}$ & 65 & 83 & & \\
Apparent digestibility, \% & & & 4.5 & 0.795 \\
stomachs, N & -0.3 & 1.6 & 1.4 & 0.195 \\
small intestine, NAN & 65.9 & 69.7 & 7.8 & 0.709 \\
large intestine, NAN & 13.5 & 8.7 & 1.4 & 0.309 \\
total tract, N & 70.5 & 73.2 & & \\
\hline
\end{tabular}

' organic matter apparently digested in the total tract

${ }^{2}$ organic matter apparently digested in the stomachs

Daily flows of AA to the duodenum and AA composition of duodenal digesta are given in Table 7 . There was only a non-significant difference $(P>0.10)$ between diets for TAA, EAA and non-essential AA (NEAA) flows to the duodenum. The AA profile of duodenal digesta was different between diets for cystine and tended to differ for lysine $(P=0.133)$, threonine $(P=0.155)$, glutamic acid $(\mathrm{P}=0.138)$ and tyrosine $(\mathrm{P}=0.168)$, all of which were higher in duodenal digesta of cows fed the FM diet. The concentration of TAA-N in NAN at the duodenum was 8.7 percentage units higher $(\mathrm{P}=0.162)$ for the $\mathrm{FM}$ diet than for the SBM diet.

The $\Lambda \Lambda$ flows to the duodenum as a percentage of $\mathrm{AA}$ intake and the distance in $\mathrm{X}^{2}$ between $\mathrm{AA}$ profiles of the diets and duodenal digesta are presented in Table 8. The duodenal flows of TAA, EAA and NEAA were lower than the respective intakes, i.e., a net disappearance of $\mathrm{AA}$ occurred in the stomachs. The values for TAA, EAA and NEAA were not different between diets $(\mathrm{P}>0.10)$. Values for individual EAA ranged from $57 \%$ for arginine in the SBM diet to $109 \%$ for methionine in the same diet. Differences between diets for duodenal EAA flow as percentage of intake were significant for arginine and methionine. Methionine flow to the duodenum was higher than intake in the SBM diet, whereas it was lower than intake in the FM diet. Values of NEAA flow to the duodenum relative to intake ranged from $40 \%$ for proline to $141 \%$ for glycine in the SBM diet. Values for glycine and alanine were higher and thosc for serine were lower for the SBM diet than for the FM diet. The distance in $\mathrm{X}^{2}$ between the 
TABLE 7

Amino acid flow to the duodenum and amino acid composition of duodenal digesta of dairy cows fed a soyabean meal or fish meal diet

\begin{tabular}{|c|c|c|c|c|}
\hline \multirow{2}{*}{ Item } & \multicolumn{2}{|c|}{ Diet } & \multirow{2}{*}{ SEM } & \multirow{2}{*}{$P$} \\
\hline & soyabean meal & fish meal & & \\
\hline $\mathrm{TAA}^{1}, \mathrm{~g} / \mathrm{day}$ & 1844 & 2408 & 399 & 0.442 \\
\hline $\mathrm{EAA}^{2}, \mathrm{~g} /$ day & 851 & 1126 & 188 & 0.316 \\
\hline $\mathrm{NEAA}^{3}, \mathrm{~g} / \mathrm{day}$ & 992 & 1283 & 211 & 0.610 \\
\hline TAA-N, g/100 g DNAN ${ }^{4}$ & 78 & 87 & 3 & 0.162 \\
\hline EAA, g/100 g TAA & 46.2 & 46.8 & 0.2 & 0.188 \\
\hline leucine & 8.0 & 7.8 & 0.7 & 0.232 \\
\hline lysine & 6.8 & 7.5 & 0.6 & 0.133 \\
\hline valine & 6.1 & 5.9 & 1.4 & 0.588 \\
\hline arginine & 5.3 & 5.8 & 2.1 & 0.200 \\
\hline threonine & 5.3 & 5.0 & 0.4 & 0.155 \\
\hline isoleucine & 5.1 & 4.9 & 1.9 & 0.486 \\
\hline phenylalanine & 4.8 & 4.5 & 2.2 & 0.291 \\
\hline histidine & 2.9 & 2.9 & 0.5 & 1.000 \\
\hline methionine & 2.1 & 2.5 & 1.3 & 0.232 \\
\hline NEAA, g/100 g TAA & 53.8 & 53.2 & 0.2 & 0.188 \\
\hline glutamic acid & 13.0 & 13.3 & 1.0 & 0.138 \\
\hline aspartic acid & 11.3 & 11.0 & 1.6 & 0.220 \\
\hline glycine & 8.1 & 8.2 & 3.2 & 0.961 \\
\hline alanine & 6.7 & 6.7 & 1.8 & 0.668 \\
\hline tyrosine & 4.6 & 4.2 & 1.5 & 0.168 \\
\hline serine & 4.3 & 4.8 & 1.6 & 0.180 \\
\hline proline & 3.5 & 3.3 & 2.5 & 0.523 \\
\hline cystine & 2.1 & 1.7 & 0.4 & 0.011 \\
\hline
\end{tabular}

' total amino acids

2 essential amino acids

${ }^{3}$ non-essential amino acids

${ }^{4}$ daily non-amonia-nitrogen flow to the duodenum

AA profiles of the diets and duodenal digesta differed between diets for TAA, EAA and NEAA and all values were higher for the SBM diet.

The disappearance of $\mathrm{A} \Lambda$ from the small intestine (Table 9) tended to be higher in cows receiving the FM diet. The percentage disappearance of TAA, EAA and NEAA from the small intestine was 5.0,6.3 and 3.8 percentage units higher for the FM diet than for the SBM diet. Significant differences between diets among EAA were determined for leucine and isoleucine and, among NEAA, for glutamic acid, alanine and serine. The lowest values of only 49.5 and $55.4 \%$ for the SBM and FM diets, respectively, were obtained for cystine. The 
TABLE 8

Amino acid flow to the duodenum as percentage of amino acid intake ${ }^{1}$ and the distance in $\mathrm{X}^{2}$ between diets and duodenal digesta of dairy cows fed a soyabean meal or fish meal diet

\begin{tabular}{|c|c|c|c|c|}
\hline \multirow{2}{*}{ Item } & \multicolumn{2}{|c|}{ Diet } & \multirow{2}{*}{ SEM } & \multirow{2}{*}{$\mathbf{P}$} \\
\hline & soyabean meal & fish meal & & \\
\hline SEM P EAA $^{2}$ & 82.2 & 83.6 & 5.1 & 0.868 \\
\hline leucine & 77.2 & 77.9 & 4.7 & 0.925 \\
\hline lysine & 85.3 & 81.7 & 4.3 & 0.606 \\
\hline valine & 90.8 & 86.4 & 3.3 & 0.457 \\
\hline arginine & 57.2 & 78.1 & 3.9 & 0.063 \\
\hline threonine & 97.6 & 89.2 & 4.2 & 0.292 \\
\hline isoleucine & 92.9 & 91.3 & 8.6 & 0.906 \\
\hline phenylalanine & 75.5 & 90.2 & 9.4 & 0.385 \\
\hline histidine & 97.2 & 88.4 & 3.8 & 0.245 \\
\hline methionine & 108.7 & 73.9 & 8.4 & 0.099 \\
\hline $\mathrm{NEAA}^{3}$ & 78.5 & 88.7 & 5.2 & 0.299 \\
\hline glutamic acid & 61.8 & 85.0 & 5.7 & 0.103 \\
\hline aspartic acid & 80.6 & 89.9 & 6.8 & 0.423 \\
\hline glycine & 141.2 & 103.4 & 4.4 & 0.026 \\
\hline alanine & 107.7 & 91.4 & 2.4 & 0.039 \\
\hline tyrosine & 104.1 & 111.8 & 5.2 & 0.408 \\
\hline serine & 71.6 & 81.2 & 2.3 & 0.095 \\
\hline proline & 40.2 & 63.6 & 7.1 & 0.146 \\
\hline cystine & 97.5 & 84.8 & 6.6 & 0.310 \\
\hline $\mathrm{TAA}^{4}$ & 80.2 & 86.2 & 5.1 & 0.491 \\
\hline \multicolumn{5}{|l|}{$\mathrm{X}^{2}$} \\
\hline EAA & 1.57 & 0.62 & 0.16 & 0.030 \\
\hline NEAA & 6.35 & 0.99 & 0.58 & 0.023 \\
\hline TAA & 7.92 & 1.35 & 0.43 & 0.008 \\
\hline
\end{tabular}

'percentages were calculated individually for each cow from the duodenal AA flow and the respective intake and then averaged. Thus, data presented in this table may deviate from values calculated on the basis of average duodenal AA flows (Table 7) and AA intakes (Table 3)

2 essential amino acids

${ }^{3}$ non-essential amino acids

${ }^{4}$ total amino acids

disappearance values of methionine and histidine in the SBM diet also were low ( 54.5 and $57.6 \%$, respectively). Although the respective values for the FM diet were 15 and 10 percentage units greater, these differences did not reach the level of significance $(P=0.211$ and $P=0.210$, respectively). For both diets, lysine and arginine were the AA that apparently disappeared to the greatest extent from the small intestine. 
TABLE 9

Disappearance of amino acids from the small intestine (\% of duodenal amino acid flow) of dairy cows fed a soyabean meal or fish mcal diet

\begin{tabular}{|c|c|c|c|c|}
\hline \multirow{2}{*}{ Item } & \multicolumn{2}{|c|}{ Diet } & \multirow{2}{*}{ SEM } & \multirow{2}{*}{$\mathbf{P}$} \\
\hline & soyabean meal & fish meal & & \\
\hline$\overline{\mathrm{EAA}^{1}}$ & 66.3 & 72.6 & 1.8 & 0.130 \\
\hline leucine & 67.4 & 73.1 & 1.1 & 0.063 \\
\hline lysine & 79.6 & 81.7 & 1.8 & 0.487 \\
\hline valine & 68.4 & 72.1 & 2.1 & 0.340 \\
\hline arginine & 80.0 & 84.2 & 1.4 & 0.157 \\
\hline threonine & 63.8 & 70.3 & 1.6 & 0.106 \\
\hline isoleucine & 67.3 & 71.4 & 0.7 & 0.061 \\
\hline phenylalanine & 68.5 & 72.3 & 0.9 & 0.104 \\
\hline histidine & 57.2 & 68.1 & 4.2 & 0.210 \\
\hline methionine & 54.5 & 70.2 & 6.1 & 0.211 \\
\hline $\mathrm{NEAA}^{2}$ & 70.7 & 74.5 & 1.4 & 0.199 \\
\hline glutamic acid & 68.0 & 73.0 & 1.2 & 0.099 \\
\hline aspartic acid & 71.2 & 72.0 & 1.4 & 0.749 \\
\hline glycine & 77.2 & 78.1 & 1.9 & 0.772 \\
\hline alanine & 61.9 & 70.2 & 1.6 & 0.065 \\
\hline tyrosine & 69.3 & 75.3 & 2.8 & 0.264 \\
\hline serine & 73.6 & 64.6 & 1.8 & 0.075 \\
\hline proline & 63.7 & 67.2 & 2.6 & 0.440 \\
\hline cystine & 49.5 & 55.4 & 4.4 & 0.447 \\
\hline TAA $^{3}$ & 68.7 & 73.6 & 1.6 & 0.160 \\
\hline
\end{tabular}

essential amino acids

2 non-essential amino acids

${ }^{3}$ total amino acids

\section{DISCUSSION}

This study was aimed at feeding the same amounts of rumen-degradable protein and rumen-degradable $\mathrm{OM}$ with both diets in order to obtain identical amounts of ruminally synthesized microbial protein. Changes in duodenal AA flow should then be due to rumen-undegraded protein from either SBM or FM. Surprisingly, differences between diets in ruminal $\mathrm{NH}_{3}-\mathrm{N}$ concentrations as an indicator of extent of ruminal proteolysis were large. Besides the slightly higher rumen-degradable CP content of the SBM diet, it appears that the SBM and FM sources of this study were more divergent in ruminal CP degradation characteristics than reported by Susmel et al. (1989), which have been used for calculation of diet composition for this trial. Our findings, however, confirm data from in situ studies reported recently by Petit (1992) and Martillotti et al. (1995) that 
rumen-degradable CP content of SBM and FM can differ by more than 20 and 15 percentage units, respectively, at assumed ruminal solid outflow rates of $5 \% / \mathrm{h}$. Lack of a clear postprandial peak of $\mathrm{NH}_{3}-\mathrm{N}$ concentrations for both diets points to a continuous release of $\mathrm{NH}_{3}$ from both $\mathrm{FM}$ and SBM. The $\mathrm{NH}_{3}-\mathrm{N}$ concentrations found for the SBM diet and those at 0,1 and $2 \mathrm{~h}$ after feeding for the FM diet were higher than $3.6 \mathrm{mmol} / 1$, a value which has been reported to be sufficient for maximal growth rates of fluid associated bacterial populations in vitro (Satter and Slyter, 1974). The values obtained for the FM diet at 5 and $8 \mathrm{~h}$ postfeeding, however, were lower than $3.6 \mathrm{mmol} / 1$. Because particle-adherent bacteria can have higher $\mathrm{N}$ requirements than those of ruminal fluid (McAllan and Smith, 1983), a temporary shortage of $\mathrm{NH}_{3}-\mathrm{N}$ in the rumen of cows fed the FM diets could have depressed ruminal fibre degradation. Ruminal digestibility of the OM including fibre components, however, was not different between diets.

Although feed intake was low and concentrates contributed no more than $60 \%$ to $\mathrm{DM}$ intake, ruminal $\mathrm{pH}$ values were low. The major concentrate ingredient was tapioca, which has been reported to contain about $80 \%$ starch and sugars with a high $(>75 \%)$ solubility (Tamminga et al., 1990). The observed trend for lower $\mathrm{pH}$ with the SBM diet may be related to rumen-degradable fibre carbohydrates of SBM (Mikled, 1986). The low ruminal fluid pH of both diets probably decreased cellulolytic activity of the bacteria and decreased fibre degradation of both diets. The optimal $\mathrm{pH}$ for cellulolytic activity of bacteria in the rumen is near 6.8 (Terry et al., 1969) and ruminal fibre degradation in vitro was almost completely inhibited at a pH of 6.0 (Stewart, 1977). The low pH could thus be responsible for the relatively low proportion $(62 \%)$ of total tract $\mathrm{OM}$ digestion that occurred in the stomachs. Because OM digestibilities in the total tract were high, post-ruminal digestion of $\mathrm{OM}$ obviously compensated for the low OM digestibility in the stomachs.

For both diets, duodenal NAN flow equaled $\mathrm{N}$ intake. Based on the observations that supply of $\mathrm{NH}_{3}$ to ruminal microbes throughout the day was closer to microbial requirements for the SBM diet than the FM diet, we suggest that microbial protein contribution to duodenal NAN flow was greater for the SBM diet. This suggestion is supported by data of Strache (1991), who used duodenal digesta from this trial and cytosine as a microbial marker and estimated that the percentage of microbial $\mathrm{N}$ of duodenal NAN flow was 5 percentage units higher for the SBM diet than for the $F M$ diet $(P<0.10)$. Because microbial CP contains more non-AA-N than rumen-undegraded $\mathrm{CP}$ due to nucleic acid- $N$, the trend observed for a greater percentage of TAA-N in NAN at the duodenum of cows fed the FM diet supports this assumption. The greater amount of rumen-undegraded CP as observed for the FM diet will be advantageous for the dairy cow only when EAA and in particular those limiting milk yield are protected from rumen degradation to the same extent as CP and 
when disappearance of $\mathrm{CP}$ from the small intestine is not decreased. The trend to greater disappearance of NAN from the small intestine of the FM diet indicates that this diet supplied more available NAN to the small intestine than the SBM diet.

With the exception of cystine, differences between diets for proportions of EAA, NEAA and individual AA in TAA of duodenal digesta could not be observed. When the AA profile of duodenal digesta was related to the profile of the diet (Table 8), however, the FM diet showed less variation. Changes in AA composition of duodenal digesta compared with the diet were expressed in $\mathrm{X}^{2}$ values. Values around 1 for the FM diet and from 1.9 to almost 8 for the SBM diet indicated that these changes were small for the FM diet but considerable for the SBM diet. Likewise, Susmel et al. (1989) have suggested that in situ rumen exposure affected the biological value of FM less than that of vegetable foods. The effect of rumen fermentation on degradation of individual AA and on AA composition of rumen undegraded protein may vary. Tamminga (1979) reported that in dairy cows fed a range of dicts methionine was degraded to a lesser extent than TAA. We found that the value of methionine in duodenal digesta as percentage of methionine intake was greater than the value of TAA for the SBM diet but lower for the FM diet. These observations indicate that methionine was less degradable than TAA in the SBM diet but more degradable than TAA in the FM diet. Variation of individual AA degradation due to diet and protein sources has also been reported by King et al. (1990) and Cozzi et al. (1995).

Different extents of postruminal AA disappearance should be accounted for when the true protein value of a feedstuffs is assessed. In vivo studies are inconsistent with respect to variation in the percentage disappearance of individual AA from the small intestine (Titgemeyer et al., 1989; Keery et al., 1993; Lebzien and Rohr, 1994). Lebzien and Rohr (1994) reported that, after correction for endogenous AA, values of AA disappearance from the small intestine did not differ between EAA and NEAA. We found that ranking of individual AA in respect of percentage disappearance from the small intestine was similar for both diets, whereas, the extent of disappearance differed largely within and between diets. The same observation has been reported for four different protein sources including SBM and FM by Titgemeyer et al. (1989). In contrast to data for EAA presented by Keery et al. (1993), the disappearance of individual AA from the small intestine was not in proportion to their concentration in the digesta flowing to the small intestine. The same authors (Keery et al., 1993) concluded that preferential absorption of NEAA occurred from the small intestine, although in their study, the EAA to NEAA ratio remained almost constant between the abomasal (0.82) and ileal (0.81) digesta. The EAA to NEAA ratios in duodenal and ileal digesta were 1.03 and 0.99 for the SBM diet and 1.04 and 0.96 for the FM diet, indicating preferential disappearan- 
ce of EAA from the small intestine. The EAA to NEAA ratio of endogenous protein from bile and pancreatic secretions of dairy cows was 0.63 and 0.05 , respectively (Hagemeister, 1987, unpublished observations). Therefore, the true difference between EAA and NEAA in disappearance from the small intestine might even be larger than reported.

\section{CONCLUSIONS}

Replacing SBM by FM in diets for dairy cows can increase the amounts of ruminally undegraded $\mathrm{CP}$ and $\mathrm{AA}$ available for digestion in and absorption from the small intestine. Ruminal fermentation had a pronounced effect on AA composition of duodenal digesta. This indicates a selective ruminal release of individual AA. Percentage disappearance of individual AA in the small intestine differed within and between SBM and FM diets. Values for percentage disappearance of individual AA from the small intestine did not reflect composition of TAA of the diets or of duodenal digesta. It can be concluded that absorbed $\mathrm{A} \Lambda$ contents of feedstuffs must be determined individually by feedstuff and AA. The observed preferential disappcarance of EAA compared with NEAA from the small intestine would increase available EAA contents for both diets.

\section{ACKNOWLEDGMENTS}

Financial support from H.W. Schaumann Stiftung, Hamburg, Germany, is gratefully acknowledged. We are indebted to Mrs. L. Stein for care of the cows. We thank Mrs. S. Bremer and the late Mr. K. Muschalla for skilled analytical assistance.

\section{REFERENCES}

Agricultural Research Council, 1980. The Nutrient Requirements of Ruminant Livestock. Commonwealth Agric. Bureau, Farnham Royal

Atwal A.S., Erf?e J.D., 1992. Effects of feeding fish meal to cows on digestibility, milk production, and milk composition. J. Dairy Sci. 75, 502-507

Brandt M., 1979. Versuche zur Quantifizierung der mik robiellen Proteinsynthese (mit Hilfe von ${ }^{15} \mathrm{~N}$ ) bei Verwendung harnstoffhaltiger Rationen. Diss., Agrarwiss. Fakultät, Christian- $\Lambda$ lbrechtsUniversität, Kiel, $115 \mathrm{pp}$. 
Brandt M., Kühn I., 1987. Photometrische Bestimmung von Cr-EDTA als Cr-DiphenylkarbazonKomplex im Darminhalt und Kot nach Kjeldahlaufschluß. Arch. Anim. Nutr. 37, 452-453

Brandt M., Süfke A., Assmus G., 1984. Fistulierung von Milchkühen im Duodenum und Ileum mit einer neuartigen Umleitungskanle aus Silikon. Z. Tierphysiol. Tierernähr. Futtermittelk. 52, 90-91

Clark J.H., Klusmeyer T.H., Cameron M.R., 1992. Microbial protein synthesis and flows of nitrogen fractions to the duodenum of dairy cows. J. Dairy Sci. 75, 2304-2323

Cozzi G., Andrighetto I., Bcrzaghi P., Polan C.E., 1995. In situ ruminal disappearance of essential amino acids in protein feedstuffs. J. Dairy Sci. 78, 161-171

Erasmus L.J., 1991. The importance of amino acid profiles for dairy cows and the significance of changes in these profiles following the use of Yea-Sacc ${ }^{1026}$. In: T.P. Lyons (Editor). Biotechnology in the Feed Industry. Proceedings of Alltech's $7^{\text {th }}$ Annual Symposium. Alltech Technical Publications, Nicholasville, KY, pp. 33-50

Guilloteau P., Toullec R., Grongnet J.F., Patureau-Mirand P., Prugnaud J., Sauvant D., 1986. Digestion of milk, fish and soya-bean protein in the preruminant calf: flow of digesta, apparent digestibility at the end of the ileum and amino acid composition of ileal digesta. Brit. J. Nutr. 55, $571-592$

Hussein H.S., Stem M.D., Jordan R.M., 1991. Influence of dietary protein and carbohydrate sources on nitrogen metabolism and carbohydrate fermentation by ruminal microbes in continuous culture. J. Anim. Sci. 69, 2123-2133

lburg M., 1993. Untersuchungen über den Bedarf lakticrender Milchkühe an einzelnen Aminosäuren. Diss., Tierärztliche Hochschulc Hannover, $120 \mathrm{pp}$.

Keery C.M., Amos H.E., Froetschel M.A., 1993. F.ffects of supplemental protein source on intraruminal fermentation, protein degradation, and amino acid absorption. J. Dairy Sci. 76, 514-524

King K.J., Huber J.T., Sadik M., Bergen W.G., Grant A.L., King V.L., 1990. Influence of dietary protein sources on the amino acid profiles available for digestion and metabolism in lactating cows. J. Dairy Sci. 73, 3208-3216

Lebzien P., Rohr K., 1994. Bestimmung der wahren Verdaulichkeit von Aminosäuren aus dem Dünndarm von Milchkühen. Arch. Anim. Nutr. 45, 355-362

McAllan A.B., Smith R.H., 1983. Factors influencing the digestion of carbohydrates between the mouth and abomasum of stecrs. Brit. J. Nutr. 50, 445-454

Martillotti F., Terramoccia S., Puppo S., Danese V., 1995. Rumen protein degradability of concentrate feeds. Zootec. Nutr. Anim. 21, Suppl. 6, 171-175

Merchen N.R., Titgemeyer E.C., 1992. Manipulation of amino acid supply to the growing ruminant. J. Anim. Sci. 70, 3238-3247

Mikled C., 1986. Untersuchungen über den intraruminalen Abbau und den Futterwert von Sojaschalen beim Wiederkäuer. Diss., Fachber. Agrarwiss., Georg-August-Universität Göttingen, $82 \mathrm{pp}$.

Naumann,. C., Bassler, R., Seibold, R., Barth, C., 1976. Die chcmische Untersuchung von Futtermitteln. In: Verband Deutscher Landwirtschaftlicher Untersuchungs- und Forschungsanstalten (Editor). Methodenbuch, Vol. 3. Verlag Neumann-Neudamm, Melsungen. Methode 4.1.1

Petit H.V., 1992. In situ degradability of feed ingredients at two proportions of concentrate.Ann. Zootech. 41, 145-152

Satter L.D., Slyter L.L., 1974. Effect of ammonia concentration on rumen microbial protein production in vitro. Brit. J. Nutr. 32, 199-208

Schröder A., Brandt M., Südekum K.-H., Lubbadeh W., 1989. Ruminal degradability of crude protein from different treated soybean meals in lactating cows. $\Lambda$ rch. $\Lambda$ nim. Nutr. 39, 333-344 
Schwab C.G., 1996. Rumen-protected amino acids for dairy cattle: Progress towards determining Jysine and methionine requirements. Anim. Feed Sci. Technol. 59, 87-101

Stewart C.S., 1977. Factors affecting the cellulolytic activity of rumen contents. Appl. Environ. Microbiol. 33, 497-502

Strache M., 1991. Zur Verwendung von Nukleobasen als Marker für mikrobielle Anteile im Chymus von Wiederkäuern. Diss., Agrarwiss. Fakultät, Christian-Albrechts-Universität, Kiel, 181 pp.

Susmel P., Stefanon B., Mills C.R., Candido M., 1989. Change in amino acid compositionof different protein sources after rumen incubation. Anim. Prod. 49, 375-383

Tamminga S., 1979. Protein degradation in the forestomachs of ruminants. J. Anim. Sci. 49, $1615-1630$

Tamminga S., van Vuuren A.M., van der Koclen C.,., Ketelaar R.S., van der Togt P.L., 1990. Ruminal behaviour of structural carbohydrates and crude protein from concentrate ingredients in dairy cows. Neth. J. Agric. Sci. 38, 513-526

Terry R.A., Tilley J.M.A., Outen G.E., 1969. Effect of $\mathrm{pH}$ on cellulose digestion under in vitro conditions. J. Sci. Food Agric. 20, 317-320

Titgemeyer E.C., Merchen N.R., Berger L.L., 1989. Evaluation of soybean meal, corn gluten meal, blood meal and fish meal as sources of nitrogen and amino acids disappearing from the small intestine of steers. J. Anim. Sci. 67, 262-275

Van Straalen W.M., 1995. Modelling of nitrogen flow and excretion in dairy cows. Ph.D. Thesis, Wageningen Agricultural University, $205 \mathrm{pp}$.

\section{STRESZCZENIE}

Ubytek aminokwasów w przewodzie pokarmowym krów otrzymujących dawki zawierające śrutę sojową lub mączkę rybną

Cztery krowy z przetokami do żwacza, dwunastnicy i jelita biodrowego żywiono dawkami zawierającymi taką samą ilość rozkładalnej w żwaczu substancji organicznej i białka ogólnego, w których głównym źródłem białka była śruta sojowa lub mączka rybna. Oznaczono ubytek substancji organiczncj, azolu i aminokwasów (AA) w jelicie cienkim i grubym. Stwierdzono tendencję do większego ubytku tych składników z jelita cienkiego krów otrrymujących mączkę rybną. Porównując skład $\Lambda \Lambda$ treści dwunastnicy i dawki wskazano, że podczas fermentacji w żwaczu profil Ai mączki rybnej zostaje zmieniony w mniejszym stopniu niż śruty sojowej. Ubytek poszczególnych AA w jelicie cienkim różnil się w obrę́bie i pomiędzy dietami. Ubytek niezbędnych AA z jelita cienkiego był większy niż niezbędnych AA.

Stwierdzono, ż wartość pokarmowa białka pasz, wyrażana jako wchłonięte $A \Lambda$, powinna być oznaczana oddziclnie dla paszy i poszczególnych $\Lambda \mathrm{A}$. 